\title{
Inkorporacja acquis Schengen do prawa Unii Europejskiej i prawa krajowego państw członkowskich
}

\author{
Artur Gruszczak, Uniwersytet Jagielloński
}

ORCID ID: 0000-0002-3450-8377

\section{Streszczenie}

Niniejszy artykuł podejmuje w formie interdyscyplinarnej analizy prawno-politologicznej problematykę włączenia acquis Schengen do prawa Unii Europejskiej oraz prawa krajowego państw członkowskich UE w świetle koncepcji hybrydowego reżimu zarządzania granicami i terytorium. Zgodnie z nią, acquis Schengen stymulowało proces krzyżowania interesów bezpieczeństwa wewnętrznego i ochrony granic państw członkowskich z ponadnarodowym imperatywem ideologicznym w odniesieniu do zasady swobodnego przepływu osób. Hipotezą badawczą w tym artykule jest założenie, że inkorporacja acquis Schengen do prawa UE ugruntowała hybrydowość prawno-instytucjonalnej konstrukcji UE po wejściu w życie traktatu amsterdamskiego wskutek sprzeczności logiki przetargu politycznego na poziomie międzyrządowym i wertykalnego spill-over wygenerowanego na poziomie ponadnarodowym $\mathrm{w}$ wymiarze instytucjonalnym i polityczno-decyzyjnym. Wnioski wskazują na ukonstytuowanie w wyniku „schengenizacji” przestrzeni wolności, bezpieczeństwa i sprawiedliwości UE, w której zasada swobodnego przepływu osób skutkowała zróżnicowaniem mechanizmów adaptacyjnych państw w odniesieniu do zdeterminowanego ideologicznie projektu transformacji systemu zarządzania terytorium i granicami w Unii Europejskiej.

Słowa kluczowe: Schengen, acquis Schengen, inkorporacja, Unia Europejska, granice

\section{The incorporation of the Schengen acquis into European Union law and the national law of the member states}

\begin{abstract}
This article takes up in the form of an interdisciplinary legal and political analysis the issue of the incorporation of the Schengen acquis into European Union law and the national legal systems of the EU member states in the light of the concept of a hybrid system of territorial governance. Accordingly, the Schengen acquis stimulated the process of intersecting the interests of internal security and the protection of Member States' borders with the supranational ideological imperative with regard to the principle of free movement of persons. The argument developed in this article is that the incorporation of the Schengen acquis into EU law consolidated hybridity of the legal and institutional construction of the EU after the Amsterdam Treaty as a result of the contradiction between the logic of political bargain at the intergovernmental level and the vertical spillover generated at the supranational level in the institutional and decision-making dimensions. The conclusions point to the emergence, as a result of "schengenisation", of the area of freedom, security
\end{abstract}


and justice in the EU, in which the principle of free movement of people brought about diversification of the states' adaptation mechanisms in relation to the ideologically determined project of transformation of the system of management of the territory and borders within the European Union.

Keywords: Schengen, acquis, incorporation, European Union, borders

\section{Wprowadzenie}

Włączenie dorobku prawnego (acquis) Schengen ${ }^{1} \mathrm{w}$ ramy Unii Europejskiej na podstawie protokołu dołączonego do traktatu amsterdamskiego z 1997 roku było ważnym wydarzeniem $\mathrm{w}$ procesie integracji europejskiej zapoczątkowanym w latach 50. XX wieku. Inkorporacja zdefiniowanego poza ramami Wspólnot Europejskich i Unii Europejskiej zestawu norm prawnych o charakterze zasadniczym i wykonawczym niosła ze sobą dalekosiężne konsekwencje dla stosowania zasady swobodnego przepływu osób we współpracy państw członkowskich UE w dziedzinie wymiaru sprawiedliwości i spraw wewnętrznych. Przede wszystkim, pogłębiała złożoność normatywnej konstrukcji UE i wielopoziomowość systemu ponadnarodowego zarządzania tą organizacją. Ponadto, pociągała za sobą istotne skutki dla prawa krajowego państw członkowskich UE ze względu na „zmienną geometrię” procesów integracyjnych toczących się na gruncie prawa Unii Europejskiej.

Niniejszy artykuł podejmuje problematykę włączenia acquis Schengen do prawa Unii Europejskiej oraz prawa krajowego państw członkowskich UE w świetle koncepcji hybrydowego zarządzania granicami i terytorium, sformułowanej przez Rubena Zaiottiego (Zaiotti 2011). Zgodnie z tą koncepcją, acquis Schengen stymulowało proces krzyżowania interesów bezpieczeństwa wewnętrznego i ochrony granic państw członkowskich z ponadnarodowym imperatywem ideologicznym odzwierciedlającym finalité politique w odniesieniu do swobody przepływu osób („,Europa bez granic"). W związku z tym, inkorporacja acquis Schengen i rozwój prawodawstwa UE na podstawie dorobku prawnego Schengen prowadziła do rozwoju norm i środków post-narodowych (mających źródło w tożsamości ponadnarodowej, europejskiej) i deterytorializacyjnych. Równocześnie implementacja norm prawnych zawartych

\footnotetext{
Chodzi przede wszystkim o umowę o stopniowym znoszeniu kontroli na wspólnych granicach zawartą 14 czerwca 1985 roku w Schengen pomiędzy Francją, RFN, Belgią, Holandią i Luksemburgiem, a także konwencję wykonawczą do układu z Schengen przyjętą 19 czerwca 1990 roku przez przedstawicieli rządów pięciu państw-sygnatariuszy umowy z 1985 roku. Do tego należy dodać protokoły akcesyjne kolejnych państw-stron układu z 1985 roku oraz akty wykonawcze przyjęte przez organy realizujące postanowienia układu z 1985 roku oraz konwencji wykonawczej z 1990 roku.
} 
w dorobku Schengen przez państwa-strony układu z 1985 roku stanowiła interesujący przykład zespolenia formy zdefiniowanej współpracy subregionalnej z hybrydowym systemem regionalnej integracji polityczno-gospodarczej (Gruszczak 2012a). Inkorporacja acquis Schengen w ramy Unii Europejskiej ujawniła hybrydowy charakter Unii Europejskiej jako formy integracji regionalnej sui generis akomodującej krzyżujące się interesy suwerennych państw członkowskich z ponadnarodowymi projektami funkcjonalnej adaptacji w ramach prawa $i$ instytucji UE.

Hipotezą badawczą w tym artykule jest założenie, że inkorporacja acquis Schengen do prawa UE ugruntowała hybrydowość prawno-instytucjonalnej konstrukcji UE po wejściu w życie traktatu amsterdamskiego wskutek sprzeczności logiki przetargu politycznego na poziomie międzyrządowym i wertykalnego spill-over wygenerowanego na poziomie ponadnarodowym w wymiarze instytucjonalnym i polityczno-decyzyjnym. Hipotezą pomocniczą jest założenie, że skutkiem „schengenizacji” współpracy w dziedzinie wymiaru sprawiedliwości i spraw wewnętrznych UE było ukonstytuowanie na mocy traktatu amsterdamskiego przestrzeni wolności, bezpieczeństwa i sprawiedliwości, w której traktatowa zasada swobodnego przepływu osób skutkowała zróżnicowaniem mechanizmów adaptacyjnych państw w odniesieniu do zdeterminowanego ideologicznie projektu transformacji granic państwowych w strefie Schengen oraz zarządzania terytorium i granicami w Unii Europejskiej.

Niniejszy artykuł zawiera interdyscyplinarną analizę łączącą elementy politologii, prawa europejskiego i stosunków międzynarodowych na gruncie studiów europejskich. Dominującą metodą jest analiza prawno-instytucjonalna, wzbogacona przez metodę analizy dogmatycznej źródeł prawa europejskiego i analizy decyzyjnej dotyczącej procesu inkorporacji dorobku prawnego Schengen w ramy Unii Europejskiej. Do weryfikacji hipotezy o różnicowaniu mechanizmów adaptacyjnych państw w kontekście inkorporacji dorobku Schengen w ramy UE posłuży metoda analizy przypadku, obejmująca trzy odmienne typy uczestnictwa w Schengen reprezentowane przez Wielką Brytanię, Norwegię i Islandię oraz Polskę.

\section{Inkorporacja acquis Schengen w ramy Unii Europejskiej}

Decyzja o włączeniu dorobku prawnego Schengen w ramy UE skomplikowała konstrukcję prawną i organizacyjną Unii, w szczególności podstawy funkcjonowania proklamowanej w Amsterdamie „przestrzeni wolności, bezpieczeństwa i sprawiedliwości”. Dalekosiężne zmiany w dziedzinie wymiaru sprawiedliwości 
i spraw wewnętrznych, funkcjonującej w luźnej, międzyrządowej formule przyjętej w Maastricht, zostały ściśle powiązane z ukonstytuowaniem strefy Schengen. Znalazło to wyraz w preambule do protokołu schengeńskiego, w której podkreślono, że przepisy składające się na acquis Schengen „mają na celu wzmocnienie integracji europejskiej i, w szczególności, umożliwienie Unii Europejskiej, aby szybciej stała się przestrzenią wolności, bezpieczeństwa i sprawiedliwości”. Zatem Schengen należało traktować jako katalizator procesów integracyjnych w odniesieniu do fundamentalnej zasady swobodnego przepływu osób, znacznie rozszerzających swój zakres w stosunku do wdrożonych do tego czasu regulacji wspólnotowych.

Reforma amsterdamska obejmowała bowiem „uwspólnotowienie” zagadnień dotyczących swobodnego przepływu osób, które do tego czasu znajdowały się - jako „sprawy wspólnego zainteresowania” - w międzyrządowym III filarze Unii Europejskiej. Decyzja o włączeniu do Wspólnoty Europejskiej (I filaru UE) polityki imigracyjnej, azylowej, wizowej, ochrony granic, celnej, a także współpracy sądowej w sprawach cywilnych, oznaczała konieczność stosowania innych instrumentów prawa pochodnego, a także inny zakres kompetencji instytucji wspólnotowych, w szczególności Komisji, Parlamentu Europejskiego i Trybunału Sprawiedliwości WE.

Acquis Schengen w chwili podpisania traktatu amsterdamskiego obejmowało nie tylko układ z 1985 roku, konwencję wykonawczą z 1990 roku oraz protokoły akcesyjne, ale także 164 decyzje i 57 deklaracji przyjętych przez Komitet Wykonawczy układu z Schengen. Ponadto, w jego zakresie znalazły się załączniki do wspólnej instrukcji wizowej, jak również obszerne podręczniki dotyczące kontroli na granicach zewnętrznych obszaru Schengen oraz mechanizmu SIRENE, odnoszącego się do udzielania dodatkowych informacji w razie pozytywnego sprawdzenia w Systemie Informacyjnym Schengen (Rokicka 2000: s. 82). Co ciekawe, do acquis włączono także pięć decyzji przyjętych przez Grupę Centralną (Zaiotti 2011: s. 156). Inkorporacja dorobku Schengen do systemu prawno-instytucjonalnego UE jawiła się wówczas - w opinii wielu ekspertów - jako proces kontrowersyjny, skomplikowany i żmudny².

Rada UE, na zasadzie jednomyślności, musiała wskazać w prawie Unii Europejskiej podstawy każdego elementu wchodzącego w skład acquis Schengen, a więc de facto rozdzielić je między I a III filar UE. Ustalono, że w razie braku jednomyślności lub formalnej podstawy w prawie traktatowym (na przykład w odniesieniu do systemów

2 Zob. krytyczne uwagi: Duff 1997: s. 9; Bribosia 1998: s. 43-46; Kuijper 2000; Rokicka 2000: s. $88-90$. 
informatycznych, takich jak SIS) dane postanowienia acquis Schengen będą traktowane jako instrumenty międzyrządowe oparte na Tytule VI TUE (a więc należące do III filaru).

W związku z powyższym, w decyzji Rady nr 1999/435/WE z 20 maja 1999 roku określono zakres acquis Schengen podlegający integracji z prawem wspólnotowym na zasadzie jednomyślności poprzez ustalenie przez Radę w ciągu pięciu lat od wejścia w życie traktatu amsterdamskiego podstaw prawnych dla każdego z dokumentów włączonych do acquis. Publikacja dorobku Schengen nastąpiła dopiero we wrześniu 2000 roku, a więc blisko trzy lata po podpisaniu traktatu amsterdamskiego. Brak oficjalnej litery całościowego dorobku prawnego Schengen częściowo utrudniał rozwój ustawodawstwa unijnego na jego podstawie, a z pewnością był przykładem naruszenia wspólnotowej kultury prawnej.

Co ciekawe, nie wszystkie decyzje przyjęte przez Komitet Wykonawczy zostały włączone w ramy prawa UE. Niektóre z nich miały poufny charakter. Początkowo, zgodnie z decyzją z 1993 roku, takich dokumentów było 13, niemniej przed przyjęciem traktatu amsterdamskiego trzy spośród nich (dotyczące spraw wizowych) zostały odtajnione. Tak więc z chwilą przyjęcia decyzji Rady nr 1999/435/WE dziesięć dokumentów zachowywało poufny status. Pięć spośród nich nie zostało włączonych w ramy prawne UE, niemniej w późniejszym okresie trzy z nich (dotyczące środków odurzających, przesyłki niejawnie nadzorowanej oraz zwalczania nielegalnego obrotu narkotykami) zostały zastąpione przez instrumenty prawa unijnego z obszaru III filaru (Thym 2002: s. 222).

„Schengenizacja” zasad przepływu osób w Unii Europejskiej doprowadziła do ukształtowania wielopoziomowego systemu prawno-instytucjonalnego wbudowanego w unijną przestrzeń wolności, bezpieczeństwa i sprawiedliwości. Z chwilą wejścia w życie traktatu amsterdamskiego, system ten obejmował trzy poziomy normatywne:

1) prawo wspólnotowe (instrumenty I filaru UE);

2) prawo Unii Europejskiej (instrumenty III filaru UE);

3) prawo międzynarodowe publiczne (uczestnictwo Norwegii i Islandii, także w pewnym zakresie - Danii, Wielkiej Brytanii i Irlandii).

Ta skomplikowana konstrukcja normatywna i instytucjonalna skutkowała zróżnicowaniem kategorii uczestnictwa w strefie Schengen, a przede wszystkim sposobów i procedur implementacji acquis Schengen. W dalszej części artykułu zostanie przedstawiona inkorporacja dorobku prawnego Schengen do prawa krajowego państw 
różniących się pod względem typu uczestnictwa w strefie Schengen. Posługując się typologią przyjętą przez Annę Szachoń-Pszenny (Szachoń-Pszenny 2014a: s. 292), przeanalizowane zostaną przypadki: Zjednoczonego Królestwa Wielkiej Brytanii i Irlandii Północnej - jako przykładu uczestnictwa wybiórczego; Norwegii i Islandii - jako przykładu uczestnictwa bez członkostwa w UE; Polski - jako uczestnictwa pełnego.

\section{Inkorporacja à la carte - przykład Wielkiej Brytanii}

Zjednoczone Królestwo Wielkiej Brytanii i Irlandii Północnej nie jest stroną układu z Schengen. Odrębne regulacje ruchu osobowego z Irlandią (tzw. wspólny obszar podróżowania) $^{3}$, wyspiarskie położenie oraz względy bezpieczeństwa wewnętrznego, nie wspominając o specyficznej kulturze politycznej i systemie prawa (common law), były głównymi przyczynami nieuczestniczenia w integracji na podstawie acquis Schengen. Do tego należałoby wspomnieć o przesłankach polityczno-ideologicznych, szczególnie wyrazistych w okresie długoletnich rządów konserwatystów (1979-1997). Rząd brytyjski twierdził, że całkowite zniesienie kontroli granicznych w strefie Schengen ułatwi działalność terrorystyczną, przemyt narkotyków, nielegalną imigrację, a nawet będzie sprzyjać szerzeniu się chorób roznoszonych przez zwierzęta (Aas 2007: s. 80).

Mimo to przedstawiciele Zjednoczonego Królestwa aktywnie uczestniczyli w pracach konferencji międzyrządowej w latach 1996-1997 przygotowującej reformę traktatową, która obejmowała między innymi włączenie acquis Schengen w ramy UE. Przeciwstawiając się uwspólnotowieniu zasad przepływu osób w Unii Europejskiej, Londyn wynegocjował specjalny status przewidujący wyłączenie (opt-out) z postanowień dotyczących „wizy, azylu, imigracji i innych polityk związanych ze swobodnym przepływem osób" (tytuł IV TWE). W związku z tym protokół włączający dorobek Schengen w ramy Unii Europejskiej zawierał także postanowienia dotyczące Zjednoczonego Królestwa (oraz Irlandii). Otwierał przed Wielką Brytanią i Irlandią możliwość zastosowania w każdym czasie niektórych lub wszystkich postanowień dorobku prawnego Schengen (Hedemann-Robinson 1999). Art. 4 protokołu stanowił, że „Irlandia oraz Zjednoczone Królestwo Wielkiej Brytanii i Irlandii Północnej [...] mogą w każdej chwili wystąpić z wnioskiem o zastosowanie wobec nich wszystkich lub niektórych przepisów tego dorobku. Rada rozstrzyga o takim wniosku,

3 Obszar wspólnego podróżowania (Common Travel Area) obejmuje także grupę wysp położonych w kanale La Manche, w skład których wchodzą Wyspy Normandzkie i Wyspa Man. Mają one status tzw. dependencji Zjednoczonego Królestwa: nie są częścią terytorium Wielkiej Brytanii oraz nie należą do Unii Europejskiej. Zob. Ryan 2001: s. 856; Szachoń-Pszenny 2014b: s. 34-35. 
stanowiąc na zasadzie jednomyślności swych członków [...] i przedstawiciela rządu państwa, którego ten wniosek dotyczy".

Z kolei art. 5 protokołu odnosi się do środków prawnych przyjmowanych na podstawie acquis Schengen i określa mechanizm umożliwiający Wielkiej Brytanii i Irlandii nieuczestniczenie w takich środkach prawnych. Stanowi, że w przypadku, gdy oba te państwa, lub jedno z nich, nie notyfikowały przewodniczącemu Rady UE woli przyjęcia takich środków, przyjmuje się, że pozostałe państwa członkowskie UE mogą je przyjąć i stosować, z udziałem lub bez udziału Wielkiej Brytanii, lub Irlandii. Dawało to dużą dowolność wyboru przez Wielką Brytanię (a także Irlandię) środków prawnych i potencjalnie miało negatywny wpływ na spójność i przejrzystość praktyki implementacji środków prawnych na podstawie dorobku prawnego Schengen ${ }^{4}$.

Co więcej, Wielka Brytania początkowo uznawała rozłączność postanowień art. 4 i 5 protokołu schengeńskiego, co miałoby skutkować możliwością uczestnictwa rządu Zjednoczonego Królestwa w rozwoju acquis Schengen (czyli udziału w przyjmowaniu środków formułowanych na podstawie dorobku prawnego Schengen). Rząd brytyjski przytaczał treść deklaracji nr 46 odnoszącej się do art. 5 protokołu w sprawie dorobku Schengen, dołączonej do traktatu amsterdamskiego, w której państwa członkowskie deklarowały zamiar ,podjęcia wszelkich wysiłków w celu umożliwienia działań wszystkich państw członkowskich w dziedzinach objętych dorobkiem Schengen, w szczególności wówczas, gdy Irlandia i Zjednoczone Królestwo Wielkiej Brytanii i Irlandii Północnej przyjęły częściowo lub w pełni ten dorobek, zgodnie z art. 4 protokołu włączającego acquis Schengen w ramy Unii Europejskiej” (Declaration on Article 5).

Jak podkreślał Michał Martela „W opinii brytyjskiej deklaracja ta zawiera domniemaną, udzieloną a priori zgodę wszystkich państw członkowskich na udział Wielkiej Brytanii i Irlandii we wszystkich środkach, w stosunku do których złożą one wymaganą notyfikację" (Martela 2007: s. 25). Z kolei Rada stała na stanowisku, że Wielka Brytania może włączyć się w stosowanie nowego środka prawnego przyjętego na podstawie acquis Schengen tylko wówczas, gdy państwo to uzna za wiążący cały obszar materii prawa UE, którego określony środek dotyczy.

Spór między rządem Zjednoczonego Królestwa a Radą Unii Europejskiej doprowadził do wniesienia przez rząd brytyjski kilku skarg do Trybunału Sprawiedliwości Wspólnot Europejskich (ETS) i precedensowych wyroków (zob. Case C-77/05; Case C-137/05; Case C-482/08). ETS odrzucił brytyjską interpretację art. 4 i 5 protokołu

\footnotetext{
4 Tak twierdzi Michał Martela (Martela 2007: s. 23-24).
} 
schengeńskiego, potwierdzając, że środki formułowane na podstawie acquis Schengen mogą być przyjmowane tylko przez państwa, które przystąpiły do układu z Schengen oraz respektują przepisy tworzone na jego podstawie. W związku z powyższym ETS uznał, że zakwalifikowanie instrumentu prawa UE jako sformułowanego na podstawie dorobku prawnego Schengen musi uwzględniać obiektywne czynniki, w szczególności cel i treść danego aktu (Cornelisse 2014: s. 755-756).

Partycypacja Zjednoczonego Królestwa w środkach przyjętych na podstawie dorobku Schengen opiera się na procedurze opting in przewidzianej w art. 4 protokołu schengeńskiego. Wielka Brytania postanowiła skorzystać z „klauzuli włączającej” i w lipcu 1999 roku zwróciła się do Rady UE z prośbą o uczestnictwo w tych postanowieniach acquis Schengen, które dotyczą współpracy policyjnej i sądowej w sprawach karnych, walki z narkotykami oraz SIS. W maju 2000 roku Rada UE wydała decyzję o zastosowaniu niektórych przepisów acquis Schengen. Wielka Brytania mogła uczestniczyć we współpracy policyjnej (ale z wyłączeniem pościgu transgranicznego), współpracy sądowej w sprawach karnych oraz współpracy w zwalczaniu przemytu i handlu narkotykami, a także korzystania w ograniczonym zakresie z Systemu Informacyjnego Schengen.

\section{Inkorporacja przez europeizację - przykład Islandii i Norwegii}

Współpraca krajów nordyckich w zakresie liberalizacji przepływu osób, podjęta w pierwszej połowie lat 50. XX wieku, była ewenementem w skali światowej. Jej rdzeniem była konwencja o zniesieniu kontroli paszportowej na granicach wewnątrznordyckich, konstytuująca tzw. Nordycki Związek Paszportowy. Podpisana 12 lipca 1957 roku w Kopenhadze (przez przedstawicieli Danii, Norwegii, Szwecji i Finlandii, do której w 1965 roku przystąpiła Islandia) konwencja wprowadzała liberalne zasady przekraczania granic wewnętrznych zarówno przez obywateli państw-stron konwencji, jak i cudzoziemców. Każdy cudzoziemiec mógł poruszać się po terytorium państw-sygnatariuszy w okresie do trzech miesięcy od daty przekroczenia granicy zewnętrznej obszaru nordyckiego bez poddawania się kontroli. Kontrola paszportowa została przeniesiona na granice zewnętrzne i usytuowana na przejściach lądowych, w portach morskich i lotniczych (Fode 1993: s. 63-64; Gruszczak 2012b).

Powstanie strefy Schengen w 1985 roku nie mogło pozostać obojętne dla państw nordyckich. Tym bardziej, że „zmienna geometria” zaangażowania w procesy integracji europejskiej pogłębiła się w wyniku kolejnego rozszerzenia Unii Europejskiej 
1 stycznia 1995 roku, w wyniku którego dwa państwa nordyckie: Szwecja i Finlandia stały się członkami UE. Ponadto Dania była żywotnie zainteresowana przystąpieniem do układu z Schengen (van de Rijt 1997: s. 30). Przed Nordyckim Związkiem Paszportowym pojawiła się groźba poważnego kryzysu, zwłaszcza, że konwencja wykonawcza do układu z Schengen w art. 140 ust. 1 ograniczała członkostwo w strefie Schengen do państw Unii Europejskiej.

27 lutego 1995 roku w Reykjaviku odbyło się spotkanie szefów rządów Rady Nordyckiej, podczas którego uzgodniono podjęcie działań dostosowujących zasady Nordyckiego Związku Paszportowego z konwencją wykonawczą Schengen (Cullen 1995: s. 81). Państwa członkowskie UE ze zrozumieniem przyjęły deklarację krajów nordyckich o zamiarze zachowania właściwości Związku Paszportowego i wyraziły zgodę na podjęcie dalszych działań (Bonnén, Søsted 2003: s. 25-26). 19 grudnia 1996 roku w Luksemburgu państwa nordyckie uczyniły pierwszy krok w kierunku włączenia ich terytoriów do strefy Schengen. Dania, Szwecja i Finlandia podpisały protokoły o przyjęciu dorobku prawnego Schengen, natomiast Islandia i Norwegia zawarły porozumienie stowarzyszeniowe o współpracy z państwami-stronami układu z Schengen w zakresie stopniowego stosowania i rozwoju acquis Schengen. Ponieważ możliwość przystąpienia państw spoza UE do strefy Schengen budziła nadal wątpliwości w świetle art. 140 KWUS, więc podczas prac nad reformą traktatową Unii Europejskiej zadbano, by nadać staraniom Islandii i Norwegii o członkostwo w Schengen sankcję traktatową. Na mocy art. 6 protokołu schengeńskiego Islandia i Norwegia włączyły się we wprowadzanie w życie dorobku Schengen i w jego dalszy rozwój. W protokole zdecydowano, że Rada stanowiąca na zasadzie jednomyślności podejmie decyzję o zawarciu porozumienia z Islandią i Norwegią zawierającego szczegółowe uregulowania ich statusu. 17 maja 1999 roku Rada UE podjęła decyzję nr 1999/439/WE o zawarciu porozumienia o stowarzyszeniu Islandii i Norwegii w zakresie wdrożenia, stosowania i rozwoju dorobku prawnego Schengen. Następnego dnia ministrowie spraw zagranicznych obu państw oraz przewodniczący Sekretariatu Generalnego Rady podpisali porozumienie stowarzyszeniowe, dające Islandii i Norwegii możliwość uczestniczenia w strefie Schengen.

Umowa ta, zastępująca porozumienie luksemburskie z 1996 roku, dotyczyła wdrożenia przez te dwa kraje określonych w aneksie do układu elementów dorobku prawnego Schengen, umożliwiających włączenie terytorium tych państw do strefy Schengen oraz stosowanie podstawowych regulacji dotyczących poruszania się po tej strefie, wjazdu 
i pobytu cudzoziemców, a także współpracy organów ścigania i organów sądowych w celu zapewnienia bezpieczeństwa na tym obszarze. Ustalono, że głównym organem realizującym stowarzyszenie Islandii i Norwegii z Schengen będzie Komitet Mieszany obradujący w zależności od potrzeb na poziomie ministrów, wysokich urzędników lub ekspertów. Przedstawiciele Islandii i Norwegii otrzymali prawo „zgłaszania sugestii” odnoszących się do projektów aktów prawnych dyskutowanych przez Radę, choć mogli to uczynić tylko za pośrednictwem Komisji Europejskiej lub któregokolwiek z państw członkowskich. Komisja została zobowiązana do nieformalnych konsultacji $\mathrm{z}$ ekspertami islandzkimi i norweskimi w sprawie projektów aktów prawnych. W art. 13 ust. 3 porozumienia podkreślono, że nie narusza ono zasad współpracy w ramach Nordyckiego Związku Paszportowego, pod warunkiem ich zgodności z postanowieniami tego porozumienia oraz środków wykonawczych.

Umowa stowarzyszeniowa w większym stopniu sankcjonowała współpracę nordycką w istniejącej formie, niż tworzyła podstawy rozwoju współpracy Islandii i Norwegii z państwami Unii Europejskiej w ramach proklamowanej w Amsterdamie przestrzeni wolności, bezpieczeństwa i sprawiedliwości5. „Klauzula zachowawcza” sformułowana w art. 13 ust. 3 umowy otwierała możliwość podążania dotychczasową ścieżką współpracy nordyckiej. Ponadto umowa wyłączała Islandię i Norwegię ze stosowania niektórych zasad współpracy schengeńskiej, takich jak wybrane elementy polityki azylowej czy kontrola celna na granicach wewnętrznych. Co więcej, rozwój ustawodawstwa unijnego na podstawie acquis Schengen może odbywać się bez udziału obydwu krajów. Umowa w art. 8 ust. 2 lit. a stanowiła, że Islandia i Norwegia podejmują niezależnie decyzję, czy przyjmują nowe akty i środki prawne przyjęte przez instytucje Wspólnot Europejskich w zakresie wiążącym obydwa państwa na podstawie umowy stowarzyszeniowej i czy dokonają ich implementacji do krajowych porządków prawnych. Otrzymały więc one do dyspozycji „klauzulę wyłączającą” uzależniającą stosowanie przez nie środków prawa UE rozwijających acquis Schengen od złożenia stosownego oświadczenia w Radzie i Komisji.

Umowa stowarzyszeniowa weszła w życie 26 czerwca 2000 roku, niemniej wdrażanie jej postanowień przez Norwegię i Islandię nastręczało wielu problemów, takich jak:

- $\quad$ wątpliwości dotyczące zgodności acquis Schengen z prawem krajowym;

- różne regulacje prawne dotyczące przetwarzania danych osobowych w systemach informatycznych;

$5 \quad$ Tak twierdzi Peter Cullen (Cullen 2001: s. 72). 
- wątpliwości dotyczące zabezpieczeń dostępu i przesyłania danych do SIS z ruchomych terminali, upowszechnionych na rozległym terytorium krajów nordyckich;

- brak jednolitego systemu ostrzegawczego w razie ujawnienia zgodności sprawdzanych danych z wpisem istniejącym w systemie;

- odmienny model zarządzania krajowym modułem Schengen przyjęty przez Danię i Islandię, polegający na powierzeniu tego zadania firmom prywatnym, co budziło wątpliwości w aspekcie bezpieczeństwa systemu;

- konieczność przeszkolenia pracowników technicznych i funkcjonariuszy upoważnionych do dostępu do Systemu Informacyjnego Schengen oraz biur SIRENE;

- różnice terminologiczne w odniesieniu do instytucji ekstradycji i związanej z tym współpracy sądowej w sprawach karnych (European Report 24.05.2000).

Ostatecznie te wątpliwości zostały rozwiane i 25 marca 2001 roku, w szesnastą rocznicę powstania strefy Schengen, pięć państw nordyckich: Dania, Szwecja, Norwegia, Finlandia i Islandia, zostało włączonych do tego obszaru. Kontrole graniczne między tymi państwami a krajami Unii Europejskiej zostały zniesione.

\section{Inkorporacja przez akcesję do UE - przykład Polski}

Już w początkowym etapie dochodzenia Polski do członkostwa w Unii Europejskiej przyjęto założenie o ścisłym związku akcesji do UE z włączeniem terytorium Rzeczypospolitej Polskiej do obszaru Schengen. W pierwszym całościowym stanowisku rządu RP dotyczącym integracji z UE - Narodowej Strategii Integracyjnej z 28 stycznia 1997 roku, stwierdzono, że celem nadrzędnym jest ,,pełne włączenie Polski do współpracy z UE i jej państwami członkowskimi, a w następstwie tego m.in. przystąpienie Polski do Układu z Schengen, zapewniającego pełną swobodę przekraczania granic przez obywateli [...]" (Komitet Integracji Europejskiej 1997).

Protokół schengeński w art. 8 postanawiał, że w procesie negocjacji dotyczących przystąpienia nowych państw do Unii Europejskiej dorobek prawny Schengen oraz dalsze środki przyjęte na jego podstawie będą traktowane jako część acquis, które musi być w pełni przyjęte przez wszystkie państwa kandydujące do członkostwa w Unii. Tym samym Polska, podejmując negocjacje akcesyjne, została zobowiązana do przyjęcia acquis Schengen. To jednak nie oznaczało, że z chwilą przyjęcia przez Unię nowych państw członkowskich ich terytoria zostaną włączone do strefy Schen- 
gen. Ze względu na opóźnienia w przygotowaniach do zniesienia kontroli na granicach wewnętrznych zgodnie z zasadami dorobku prawnego Schengen, państwa, które podpisały w 2003 roku traktat akcesyjny, zgodziły się na uzależnienie terminu zniesienia kontroli na granicach wewnętrznych z państwami strefy Schengen od decyzji Rady UE po spełnieniu wymogów dostosowawczych i przejściu pomyślnej ewaluacji (Radzikowska-Kryśczak, Sadownik 2008).

Polska z chwilą przystąpienia do Unii Europejskiej została zobowiązana do stosowania niektórych przepisów Schengen: dotyczących kontroli granic zewnętrznych, walki z nielegalną imigracją, współpracy sądowej w sprawach karnych, wybranych aspektów współpracy policyjnej, zwalczania przemytu narkotyków, handlu i przemytu broni, ochrony danych osobowych. Inne postanowienia, dotyczące przede wszystkim warunków zniesienia kontroli na granicach wewnętrznych państw strefy Schengen, funkcjonowania SIS, niektórych elementów polityki wizowej oraz najważniejszych zasad współpracy policyjnej (obserwacja i pościg transgraniczny), podlegały ocenie przez Grupę Ewaluacyjną Rady UE (Martela 2005). Zatem inkorporacja dorobku Schengen do polskiego prawa dokonała się w zasadniczej mierze w ramach negocjacji akcesyjnych z UE, należąc do 24. rozdziału (obszaru negocjacyjnego) - wymiar sprawiedliwości i sprawy wewnętrzne.

Z uwagi na skalę przygotowań Polski do włączenia do strefy Schengen, zwłaszcza gruntownej modernizacji i rozbudowy infrastruktury na wschodniej granicy państwa (w przyszłości zewnętrznej granicy strefy Schengen), w akcie akcesyjnym Polski do UE przewidziano specjalne środki finansowe (tzw. ułatwienia schengeńskie), których celem było wsparcie wysiłków związanych z przygotowaniami do pełnego uczestnictwa w Schengen ${ }^{6}$. Polska w latach 2004-2006 otrzymała 311 mln euro na: budowę, remont lub modernizację elementów infrastruktury granicznej; zakup wyposażenia, oprogramowania komputerowego i środków transportu; szkolenia straży granicznej; dofinansowanie działań logistycznych i operacyjnych. Ponadto w ramach Norweskiego Mechanizmu Finansowego na wdrażanie przepisów schengeńskich oraz wzmacnianie sądownictwa przyznano $113 \mathrm{mln}$ euro do 2009 roku.

W styczniu 2006 roku Grupa Ewaluacyjna Rady UE rozpoczęła procedurę oceny przygotowań nowych krajów członkowskich do pełnego wejścia do strefy Schengen

6 Do pomocy finansowej w ramach ułatwień schengeńskich kwalifikowały się: inwestowanie w budowę, remont lub unowocześnienie infrastruktury granicznej; zakup wyposażenia, oprogramowania komputerowego i środków transportu; szkolenia straży granicznej; dofinansowanie działań logistycznych i operacyjnych. 
(Gruszczak, Reczkin 2006). Tymczasem główną przeszkodą były niezależne od Polski opóźnienia w budowie Systemu Informacyjnego Schengen nowej generacji, do którego zostałyby podłączone nowe państwa członkowskie UE. Dzięki inicjatywie Portugalii, która zaproponowała rozwiązanie systemowe, tzw. SISone4all, umożliwiające użytkowanie przez nowe państwa członkowskie udostępnionego przez Portugalię oprogramowania krajowego modułu SIS, terytoria dziewięciu nowych państw członkowskich, wśród nich Polski, z dniem 21 grudnia 2007 roku zostały włączone do strefy Schengen.

\section{Uwagi końcowe}

Państwa członkowskie, dokonując reformy traktatowej w 1997 roku, zdecydowały o włączeniu dorobku prawnego Schengen w ramy Unii Europejskiej w przekonaniu, że prawno-instytucjonalne i polityczne podstawy integracji nadadzą obszarowi Schengen odpowiednio wysoką rangę oraz podniosą efektywność mechanizmów kontroli granic i bezpieczeństwa wewnętrznego. Hybrydowe zarządzanie terytorium, granicami i ludnością w strefie Schengen wymusiło wprowadzenie i stosowanie skomplikowanych, nie zawsze skutecznych, lecz wymagających mechanizmów i procedur odpowiadających za utrzymujące się tarcia między działaniami ponadnarodowymi kierowanymi przez instytucje UE a międzyrządową współpracą determinowaną przez państwa członkowskie. Odmiany inkorporacji dorobku Schengen do prawa krajowego, przedstawione powyżej na przykładach ilustrujących trzy typy uczestnictwa w Schengen, potwierdziły hipotezę o zróżnicowaniu mechanizmów adaptacyjnych państw w odniesieniu do schengeńskiego systemu zarządzania terytorium i granicami.

W ostatnich latach hybrydowość Schengen prowadzi w kierunku odchodzącym od koncepcji Rubena Zaiottiego. Zmierza ku renacjonalizacji polityki zarządzania terytorium oraz odbudowy instytucji granicy państwowej jako elementu schengenizacji polityki imigracyjnej Unii Europejskiej. Utrzymywanie od prawie trzech lat kontroli na granicach wewnętrznych przez sześć państw obszaru Schengen jest wymownym tego dowodem. Przesunięcie punktu ciężkości na uregulowania flankowe, w szczególności wzmocnienie ochrony południowych i wschodnich odcinków granicy zewnętrznej strefy Schengen, uwarunkowane jest obawą wielu państw tej strefy przed zaburzeniami równowagi społecznej, ładu publicznego, a także zagrożeniami bezpieczeństwa wewnętrznego. Blokowanie rozszerzenia obszaru Schengen o trzy państwa członkowskie UE: Bułgarię, Rumunię i Chorwację przez pojedyncze kraje świadczy 
o prymacie narodowych interesów nad proeuropejską orientacją ich krajowych polityk. Te oznaki wróżą sporą niepewność i rodzą wyzwania w związku z nieuchronną kontynuacją reformy prawodawstwa UE opartego na acquis Schengen.

Artur Gruszczak - profesor nadzwyczajny w Instytucie Nauk Politycznych i Stosunków Międzynarodowych Uniwersytetu Jagiellońskiego, kierownik Zakładu Bezpieczeństwa Narodowego. Zajmuje się problematyką bezpieczeństwa, przestrzeni wolności, bezpieczeństwa i sprawiedliwości UE, współpracy wywiadowczej w Unii Europejskiej. Ostatnie publikacje obejmują: Technology, Ethics and the Protocols of Modern War (Routledge, 2018, współredaktor wraz z P. Frankowskim), Cross-Disciplinary Perspectives on Regional and Global Security (Palgrave Macmillan, 2018, współredaktor wraz z P. Frankowskim), Intelligence Security in the European Union. Building a Strategic Intelligence Community (Palgrave Macmillan, 2016).

Adres e-mail: artur.gruszczak@uj.edu.pl

Artur Gruszczak - habilitated doctor, an associate professor at the Institute of Political Sciences and International Relations of Jagiellonian University in Krakow, Poland, the chair of the National Security Department. His research areas include: security studies, EU area of freedom, security and justice, intelligence cooperation in the European Union. Recent publications: Technology, Ethics and the Protocols of Modern War (Routledge, 2018, co-editor with P. Frankowski), Cross-Disciplinary Perspectives on Regional and Global Security (Palgrave Macmillan, 2018, co-editor with P. Frankowski), Intelligence Security in the European Union. Building a Strategic Intelligence Community (Palgrave Macmillan, 2016).

E-mail address: artur.gruszczak@uj.edu.pl

\section{Bibliografia}

AAS Katja Franko (2007), Globalization and Crime, London-Thousand Oaks-New Delhi-Singapore.

BONNÉN Preben, SØSTED Michael (2003), The Origin, Development and Perspectives of Nordic Co-operation in a New and Enlarged European Union, „Österreichische Zeitschriftfür Politikwissenschaft”, nr 1.

BRIBOSIA Hervé (1998), Liberté, sécurité et justice: l'imbroglio d'un nouvel espace, „Revue du Marché Unique Européen”, nr 1.

CASE C-77/05 (2007), United Kingdom v. Council of the European Union, „European Court Records", I-11459.

CASE C-137/05 (2007), United Kingdom v. Council of the European Union, „European Court Records", I-11593.

CASE C-482/08 (2010), United Kingdom v. Council of the European Union, „European Court Records", I-10413. 
CORNELISSE Galina (2014), What's Wrong with Schengen? Border Disputes and the Nature of Integration in the Area Without Internal Borders, ,Common Market Law Review", nr 3.

CULLEN David (1995), Variable Geometry And Overlapping Circles: In Search of a Suitable Model for Justice and Home Affairs, w: Ronald Bieber, JörgMonar (red.), Justice and Home Affairs in the European Union. The Development of the Third Pillar, Brussels.

CULLEN Peter (2001), The Schengen Agreement with Iceland and Norway: Its Main Features, „ERA Forum”, nr 4.

DECLARATION ON ARTICLE 5 (1997) of the Protocol integrating the Schengen acquis into the framework of the European Union, w: Treaty of Amsterdam amending the Treaty on European Union, the Treaties establishing the European Communities and certain related acts, Luxembourg.

DUFF Andrew (red.), (1997), The Treaty of Amsterdam. Text and Commentary, London.

EUROPEAN REPORT, Free Movement: Accession of Nordic Passport Union to Schengen Area Postponed. (24.05.2000).

FODE Henning (1993), Cooperation on Law Enforcement, Criminal Justice and Legislation in Europe. Nordic Experience, w: Henry Schermers et al. (red.), Free Movement of Persons in Europe. Legal Problems and Experiences, Dordrecht-Boston-London.

GRUSZCZAK Artur (2012a), Schengen - kłopotliwy sukces, „Nowa Europa. Przegląd Natoliński”, nr 2(13).

GRUSZCZAK Artur (2012b), Cooperation of Nordic Countries in the Field of Internal Security, w: Ryszard M. Czarny et al. (red.), The Northern Spaces - Contemporary Issues, Warszawa-Kielce.

GRUSZCZAK Artur, RECZKIN Karol (red.), (2006), Polska i Schengen - ostatnia prosta czy poczatek trudnej drogi?, „Materiały Robocze Forum”, nr 1(5), Warszawa.

HEDEMANN-ROBINSON Martin (1999), The Area of Freedom, Security and Justice with Regard to the UK, Ireland and Denmark: The 'Opt-in Opt-outs' under the Treaty of Amsterdam, w: David O'Keeffe, Patrick Twomey (red.), Legal Issues of the Amsterdam Treaty, Oxford-Portland.

KOMITET INTEGRACJI EUROPEJSKIEJ (1997), Narodowa Strategia Integracji, Warszawa.

KUIJPER Pieter Jan (2000), Some Legal Problems Associated with the Communitarization of Policy on Visas, Asylum and Immigration Under the Amsterdam Treaty 
and Incorporation of the Schengen Acquis, „Common Market Law Review”, $\mathrm{nr} 2$.

MARTELA Michał (2005), Ocena stosowania dorobku prawnego Schengen - ewaluacja Schengen, „Przegląd Prawa Europejskiego”, nr 1(19).

MARTELA Michał (2007), Problematyka stosowania przez Wielka Brytanię i Irlandię postanowień Tytułu IV TWE, „Materiały Robocze Forum” nr 1(11), Warszawa.

RADZIKOWSKA-KRYŚCZAK Barbara, SADOWNIK Anna (red.), (2008), Polska w strefie Schengen. Refleksje po pierwszym roku czlonkostwa, Warszawa.

ROKICKA Karolina (2000), Wtaczenie acquis Schengen w ramy prawne Unii Europejskiej, „Studia Europejskie”, nr 2(14).

RYAN Bernard (2001), The Common Travel Area between Britain and Ireland, „The Modern Law Review”, nr 6.

SZACHOŃ-PSZENNY Anna (2014a), Polska jako państwo członkowskie strefy Schengen na tle innych typów uczestnictwa w acquis Schengen, w: Artur Kuś, Anna Szachon-Pszenny (red.), Wplyw acquis communautaire i acquis Schengen na prawo polskie - doświadczenia i perspektywy. Tom II - 15 lat acquis Schengen w prawie Unii Europejskiej, Lublin.

SZACHOŃ-PSZENNY Anna (2014b), Wymiar prawny i terytorialny strefy Schengen, w: Monika Trojanowska-Strzęboszewska (red.), System Schengen a imigracja z perspektywy Polski i Niemiec, Warszawa.

THYM Daniel (2002), The Schengen Law: A Challenge for Legal Accountability in the European Union, „European Law Journal”, nr 2.

VAN DE RIJT Wouter (1997), Schengen et les pays nordiques: aperçu de la situation actuelle, w: Monica den Boer (red.), Schengen, Judicial Cooperation and Policy Coordination, Maastricht.

ZAIOTTI Ruben (2011), Cultures of Border Control.Schengen and the Evolution of European Frontiers, Chicago-London. 